\title{
Transcription Factor Jun-B
}

National Cancer Institute

\section{Source}

National Cancer Institute. Transcription Factor Jun-B. NCI Thesaurus. Code C17462.

Transcription factor jun-B (347 aa, $\sim 36 \mathrm{kDa}$ ) is encoded by the human JUNB gene. This protein is involved in the modulation of transcription. 